\title{
A comparative investigation of entrepreneurship in Iran and countries of Global Entrepreneurship Monitor
}

\author{
Zahra Arab $^{\mathrm{a}^{*}}$ and Younos Vakil Alroaia
}

${ }^{a}$ Master Student of Industrial Management, Islamic Azad University, Semnan Branch, Semnan, Iran

${ }^{b}$ Assistant Professor, Department of Management, Semnan Branch, Islamic Azad University, Semnan , Iran

\begin{tabular}{l}
\hline A R T I C L E I N F O \\
\hline Article history: \\
Received March 22, 2012 \\
Received in Revised form \\
May, 8, 2012 \\
Accepted 11 May 2012 \\
Available online \\
May 14 2012 \\
\hline Keywords: \\
Entrepreneurship \\
Global entrepreneurship monitor \\
Entrepreneurial activities \\
Entrepreneurial perceptions \\
Structural equation modeling
\end{tabular}

\section{A B S T R A C T}

Entrepreneurship development is a complex process, which plays long-term and pervasive role in the economical development of the countries. In order to become aware of the level of entrepreneurship, many countries are interested in making comparison between their own experiences and policies and those of others which have been successful in developing entrepreneurship. This study aims at making a comparative investigation of entrepreneurship in Iran and countries of global entrepreneurship monitor. Structural equation modeling was used to study the effect of independent variables of entrepreneurial activities and entrepreneurial perceptions between 2008 until 2010. The results show that entrepreneurial perceptions have a significant effect on entrepreneurial activities and observed variables have a complete positive relationship with each other.

(C) 2012 Growing Science Ltd. All rights reserved.

\section{Introduction}

For more than half a century, entrepreneurship as a scientific issue has received considerable attention from well-known universities like Harvard, policy makers of international organizations like International Labor Organization (ILO) and World Bank (Shane, 2000; Venkataraman, 2002; Timmons \& Spinelli, 2004). In recent years, entrepreneurship development in countries like Iran requires systematic research studies. However, such an endeavor needs to be taken in the light of global indices and standards so that we are able to have a clear picture of entrepreneurial activities in Iran and make a comparison with the least and the most developed countries in the realm of entrepreneurship. Global Entrepreneurship Monitor (GEM), which is the pioneer of defining and designing global research indices and data in the area of entrepreneurship, presents entrepreneurial activities among its member countries through the publication of global reports (Bosma \& Schutjens, 2007).

Corresponding author. Tel: +98-912-3443139

E-mail addresses: younos.vakil@gmail.com(Y. Vakil Alroaia)

(C) 2012 Growing Science Ltd. All rights reserved.

doi: $10.5267 /$ j.msl.2012.05.016 
In 1997, GEM was launched with the cooperation of outstanding university students from England, United States, Finland, Ireland, Babson College, Business School of London, and with the strong support of Coffman entrepreneurship institution. The aim of the research project of GEM is annual estimation of entrepreneurial activities and perceptions for individual countries. Generally, the unique ability of GEM in providing the vision of a country's entrepreneurship in the international level has turned its information into an important source for serious attempts to study and scrutinize global entrepreneurial behavior. The information presents a comprehensive collection of criteria for multifaceted description of a country's entrepreneurial behavior. GEM research measures not only earlystage entrepreneurial activities, but also the index of established business owners, who are the ones that are at least 42 months old and have been paid wages. In fact, their business has passed the dangerous stage of entrepreneurship process. We can learn a lot of things by comparing nascent and established businesses (Zali, 2007).

\subsection{Entrepreneurial activities}

These are the ones which are related to launching or managing a new business which can be done by oneself or with the help of others. The definition of the concept of opportunism in entrepreneurship science is totally different from that in literature. For example, Kerzener (1973) believes that opportunities are like paper money spreading over the sidewalk which are expecting a watchful person to pick them up. In contrast, Schumpeter (1942) claims that opportunities need a lot of investment to be exploited and commitment to their exploitation can only be found in the most organized minds (De Clercq, D., \& Bosma, 2008; Bosma \& De Clercq, D., 2008). Casson and wadeson (2007) in Hike's research (1945) reflected the concept of opportunity is in localized knowledge of market factors in competitive prices, which is a symptom of relevant shortage, as well as how they change from place to place and time to time (10). Casson (1982) believes that entrepreneurial opportunities are the ones that are used for making new goods, giving new services, providing raw materials, and designing new organizing ways, all of which make it possible for the output to be sold with a price higher than that of the production (11). From krouger's (2006) perspective, opportunity is a condition which by itself will be considered desirable and possible for future decision makers. Venkatraraman (2002) defines opportunity as an idea or innovation which will lead to financial gains and believes that their achievement depends on the appropriateness of conditions and activities which make the results practical through financial artifacts. Timmons (1999) states that "in fact, opportunities constitute a process which is like particles clash in an atomic reaction or the reproduction of the fish in an ocean after the hurricane." Ideas coincide in the world of reality and as a result of entrepreneurial innovation and lead to an opportunity. Timmons believes that an opportunity must be attractive and on time, and create added value for buyer or consumer (Dellabaraca, 2002; Nawaser et al., 2011).

\subsection{Entrepreneurial perception}

Entrepreneurial perception involves perceived entrepreneurial capabilities, i.e. people's perception of their own knowledge and experience to launch a business (Bosma et al., 2008). Human beings always act based on their perception of reality, rather than reality itself. In fact, they look at the world from their own perspective. If a person thinks that s/he can start a business or recognize an opportunity, $\mathrm{s} /$ he has the ability to do it in practice. That's why it is said that if you think that you can or you cannot, most probably you are right. Therefore, a person's behavior, performance, and perspective are under the influence of their perceptions. It is due to this reason that perceiving individual capabilities and recognizing entrepreneurial opportunities is a completely perceptional topic. In other words, what is important is people's understanding of their abilities rather than their abilities themselves. It might happen that people do not have the capability to perform a job, but they think that they are able to recognize an entrepreneurial opportunity (even if there is no real opportunity). 
Anyway, the more negative is the perception people have of their own abilities, the less intensive would be their entrepreneurial activities. With respect to entrepreneurship, individual perceptions can be classified into the following categories: perceived capabilities, perceived opportunities, fear of failure, and entrepreneurial intention (Zali, 2008). Of course, these individual perceptions are greatly influenced by the entrepreneurial atmosphere, which is dominant in business. More precisely, in a suitable business environment, individuals can know their capabilities in a better way and recognize good entrepreneurial opportunities which lead to the formation of potential entrepreneurial activities (GEM, 2007). As Wennekers (2005) states, the evaluation of "opportunity costs" is a variable which moderates the possibility of the conversion of potential entrepreneurs' activities into entrepreneurial intention rate. In other words, he thinks that if entrepreneurship is an attractive option for individuals, they develop entrepreneurial intention, which finally ends up in entrepreneurial activities.

Therefore, the aim of this study is to find out empirically at making a comparative investigation of entrepreneurship in Iran and countries of global entrepreneurship monitor. In this case, the next section explains the theoretical framework of the study and methodology used in measuring entrepreneurship. The forth section finds out the decision-making processing entrepreneurship in Iran and countries. The last section is the conclusion.

\section{Theoretical framework of the study}

This study focuses on comparing entrepreneurship condition in Iran with that in GEM countries. In this regard, a conceptual model has been developed which demonstrates the relationship between latent and observed variables. In this model, the relationship between the latent variables of entrepreneurial perceptions and entrepreneurial activities has been investigated. In the case of the first variable (i.e. entrepreneurial perceptions), the observed variables are nascent entrepreneurship, earlystage entrepreneurship, new business ownership, and established business ownership. In contrast, in the case of the second one (i.e., entrepreneurial activities), observed variables are perceived opportunities, perceived capabilities, entrepreneurial intention, and fear of failure.

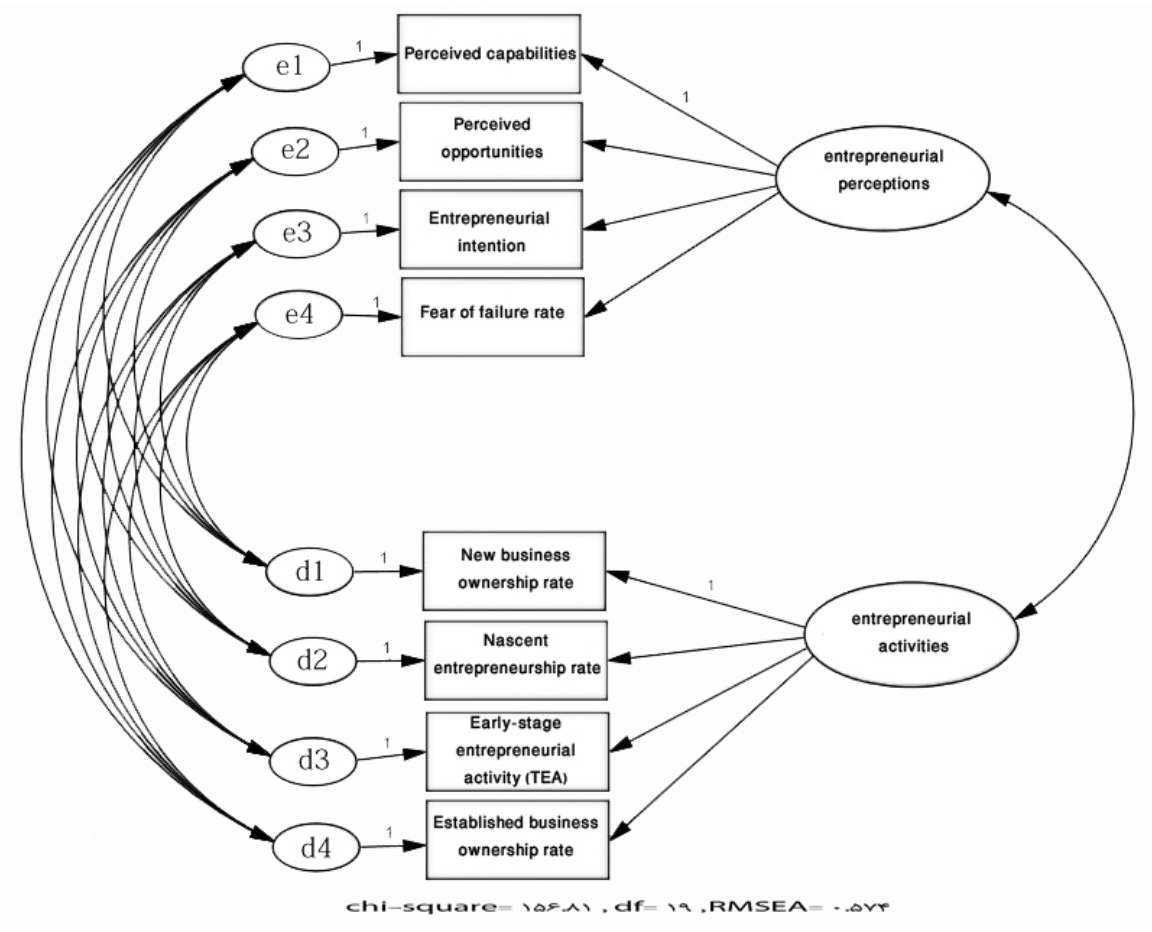

Fig.1. Conceptual model 
Table1

Research hypotheses

\begin{tabular}{ll}
\hline Hypotheses & Description of the hypotheses \\
\hline 1 & $\begin{array}{l}\text { There is a relationship between the observed variables of and those of entrepreneurial } \\
\text { activities }\end{array}$ \\
2 & $\begin{array}{l}\text { There is a relationship between the latent variable of entrepreneurial perceptions and } \\
\text { observed variables of entrepreneurial activities }\end{array}$ \\
3 & $\begin{array}{l}\text { There is a relationship between the latent variable of entrepreneurial activities and its } \\
\text { observed variables }\end{array}$ \\
4 & Entrepreneurial perceptions have an effect on entrepreneurial activities \\
\hline
\end{tabular}

\section{Methodology}

With respect to the aim, this study is classified as an applied research and, with the consideration of methodology; it is categorized as a co-relational one. The information obtained from global entrepreneurship monitor constituted the data for the study. In addition, structural equation modeling (Schumacher \& Lvmks, 2010) and AMOS software were used for data analysis. The sample included all the countries, which are the members of GEM; it included Iran and 22 OECD countries

Entrepreneurial perceptions variables introduced by GEM and have been recognized as international indices include: Nascent entrepreneurship rate, New business ownership rate, Established business ownership rate, Early-stage entrepreneurial activity (TEA) (GEM, 2010). Entrepreneurial activities variables introduced by GEM and have been recognized as international indices include: Perceived opportunities, Perceived capabilities, Entrepreneurial intention, Fear of failure rate (GEM, 2009).

In this article, Structural equation modeling was used to study the effect of independent variables of entrepreneurial activities and entrepreneurial perceptions between 2008 until 2010. Structural equation modeling is a comprehensive statistical method for testing hypotheses about the relation between observed and latent variables and is usually known as covariance structural equation modeling, causal modeling, and LISREL (Kruger et al., 2006; Schumacher \& Lvmks, 2010). However, the most famous term is structural equation modeling (SEM). There are at least four reasons for its wide use: first, researchers have become more conscious about the need to use multiple observed variables for better understanding of their scientific, research based area; second, researchers are paying more attention to the importance of the validity and reliability of the scores obtained through measurement instruments; third, in the last thirty years, SEM has been able to analyze more advanced conceptual structural models; finally, SEM softwares are increasingly becoming user friendly (Richard, 2009). Confirmatory factor model is plotted in Fig. 1 and included 8 measurement equation in the model like this:

Nascent entrepreneurship rate $=$ function of Entrepreneurial perceptions $+\mathrm{e} 1$

New business ownership rate $=$ function of Entrepreneurial perceptions + e2

Established business ownership rate $=$ function of Entrepreneurial perceptions $+\mathrm{e} 3$

Early-stage entrepreneurial activity $=$ function of Entrepreneurial perceptions + e 4

Perceived opportunities $=$ function of entrepreneurial activities $+\mathrm{d} 1$

Perceived capabilities $=$ function of entrepreneurial activities $+\mathrm{d} 2$

Entrepreneurial intention $=$ function of entrepreneurial activities $+\mathrm{d} 3$

Fear of failure rate $=$ function of entrepreneurial activities $+\mathrm{d} 4$

Most experts suggest that to increase the accuracy of the study, it is better to use several criteria for evaluating the model, to comparison economic and the models. The formula to calculate the Root Mean Square error of Approximation (RMSEA), Comparative Fit Index (CFI), Adjusted goodness of fit index (GFI) and normed fit undex (NFI) is as follows, 
$\mathrm{GFI}=1-\left(\chi_{\mathrm{m}}^{2} / \chi_{\mathrm{n}}^{2}\right)$

$\mathrm{NFI}=\left(\chi_{\mathrm{n}}^{2}-\chi_{\mathrm{m}}^{2}\right) / \chi_{\mathrm{n}}^{2}$

$\mathrm{CFI}=1-\left[\left(\chi_{\mathrm{n}}^{2}-\mathrm{df}_{\mathrm{m}}\right) /\left(\chi_{\mathrm{n}}^{2} / \mathrm{df}_{\mathrm{n}}\right)-1\right]$

RMSEA $\left.=v\left[\chi_{m}^{2}-d f_{m}\right] /(N-1) d f_{m}\right]$

\section{Empirical Result}

Based on the interpretations and the statement of competitive advantages of the enhancement of entrepreneurial perceptions, one can conclude that more than the any other time, the world's countries need to have educations on entrepreneurial perceptions as a factor, which enhances entrepreneurial activities. By so doing, they can have a suitable share in global business.

Structural equation modeling is in fact a model for drawing the relationship between variables. Its basic aim is to provide a framework for quantitative analysis of conceptual models. The present study has used data from GEM; countries' data on entrepreneurial activities and perceptions in 2008, 2009, and 2010 was collected. The basic hypothesis is that there is a relationship between entrepreneurial activities and perceptions. Table 2 demonstrates the average rate of entrepreneurial activities and perceptions of GEM members from 2008 to 2010.

Table 2

The average rate of entrepreneurial activities and perceptions of the GEM member from 2008 to 2010

\begin{tabular}{|c|c|c|c|c|c|c|c|c|c|}
\hline \multirow[b]{2}{*}{ 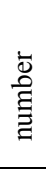 } & \multirow[t]{2}{*}{ Country } & \multicolumn{4}{|c|}{ Entrepreneurial perceptions } & \multicolumn{4}{|c|}{ entrepreneurial activities } \\
\hline & & $\begin{array}{l}\text { Establishe } \\
\mathrm{d} \text { business } \\
\text { ownership } \\
\text { rate }\end{array}$ & $\begin{array}{l}\text { Early-stage } \\
\text { entrepreneuria } \\
1 \text { activity }\end{array}$ & $\begin{array}{l}\text { Nascent } \\
\text { entrepreneurshi } \\
\text { p rate }\end{array}$ & $\begin{array}{l}\text { New } \\
\text { business } \\
\text { ownershi } \\
\text { p rate }\end{array}$ & $\begin{array}{l}\text { Entrepreneuria } \\
1 \text { intention }\end{array}$ & $\begin{array}{l}\text { Fear } \\
\text { of } \\
\text { failur } \\
\text { e rate }\end{array}$ & $\begin{array}{l}\text { Perceived } \\
\text { capabilitie } \\
\mathrm{s}\end{array}$ & $\begin{array}{l}\text { Perceived } \\
\text { opportunitie } \\
\mathrm{s}\end{array}$ \\
\hline 1 & Germany & 4.93 & 4.03 & 2.36 & 1.8 & 5.13 & 39.9 & 28.5 & 28.23 \\
\hline 2 & Spain & 7.73 & 2.93 & 2.6 & 2.93 & 4.93 & 44.46 & 22.26 & 43.56 \\
\hline 3 & Slovenia & 5.36 & 2.3 & 3.16 & 2.3 & 8.56 & 30.1 & 36.93 & 41.9 \\
\hline 4 & $\begin{array}{l}\text { United } \\
\text { kingdom }\end{array}$ & 6.16 & 3.13 & 3 & 3.13 & 4.7 & 33.43 & 31.4 & 49 \\
\hline 5 & $\begin{array}{l}\text { United } \\
\text { states }\end{array}$ & 7.3 & 3.63 & 5.2 & 3.63 & 7.23 & 27.23 & 35.6 & 49.8 \\
\hline 6 & Italy & 5.33 & 1.86 & 1.7 & 1.86 & 5 & 41.26 & 28.23 & 34.4 \\
\hline 7 & Iran & 6.86 & 11.16 & 6.3 & 5.1 & 33 & 28 & 36 & 56.86 \\
\hline 8 & Ireland & 8.7 & 7.13 & 3.85 & 3.46 & 6.03 & 34.8 & 28.5 & 30.76 \\
\hline 9 & Iceland & 7.8 & 10.7 & 7.166 & 3.7 & 14.23 & 35.23 & 43.56 & 30.63 \\
\hline 10 & Belgium & 2.6 & 3.36 & 2.1 & 4 & 6.4 & 31.03 & 25.86 & 8.96 \\
\hline 11 & Turkey & 7.83 & 4.1 & 3.45 & 3.9 & 20.13 & 32 & 40.7 & 48.36 \\
\hline 12 & Denmark & 6.16 & 5.1 & 1.9 & 2.16 & 4.63 & 37.16 & 49.8 & 22.26 \\
\hline 13 & Japan & 7.7 & 1.8 & 2.2 & 1.8 & 3.3 & 42.2 & 8.96 & 35.1 \\
\hline 14 & Switzerland & 8.36 & 3.2 & 3.15 & 3.2 & 6.96 & 28.66 & 35.1 & 48.26 \\
\hline 15 & Chile & 6.5 & 15.26 & 6.43 & 5.83 & 34.1 & 26.36 & 49 & 16 \\
\hline 16 & France & 2.8 & 5.23 & 3.53 & 1.86 & 14.4 & 46.8 & 30.63 & 25.86 \\
\hline 17 & Finland & 9.03 & 5.23 & 3.13 & 3 & 4.63 & 28.86 & 48.36 & 25.63 \\
\hline 18 & Korea & 11.93 & 5.23 & 2.66 & 5.23 & 13.7 & 32.16 & 16 & 35.6 \\
\hline 19 & Hungary & 5.8 & 7.6 & 3.53 & 3.03 & 10.93 & 40.73 & 30.76 & 28.83 \\
\hline 20 & Mexico & 4.36 & 4.06 & 9.3 & 3.83 & 23.76 & 32 & 57.2 & 36 \\
\hline 21 & $\begin{array}{l}\text { Netherland } \\
\mathrm{s}\end{array}$ & 8.1 & 3.56 & 3.06 & 3.56 & 5.166 & 26.6 & 40.26 & 36.93 \\
\hline 22 & Norway & 7.56 & 3.76 & 4.8 & 3.76 & 7.53 & 26.53 & 48.26 & 40.4 \\
\hline 23 & Egypt & 14.16 & 8.06 & 3.93 & 4.26 & 14.56 & 50.3 & 25.63 & 28.5 \\
\hline
\end{tabular}

Therefore, in the above model, first the relationships between these two variables were investigated. Then, we study the relationships between each of the latent variables such as activities and perceptions with their observed variables and the correlation between the two sets of latent variables was investigated in the last step. The important point in the above model is the existence of a negative relationship between government's technological products and innovation. Of course, it is worth 
noting that fear of failure is one of the serious obstacles for entrepreneurial development and active people's attraction to entrepreneurship. Fear of failure involves fear of losing employment and financial account, others' diatribe, and relatives', colleagues', and rivals' humiliation and domination due to failure. In fact, in a society, adults do not take any actions to practice their business ideas because of their fear of failure. Despite the limited area of the research, the obtained result demonstrates this negative relationship. Having the final model and assuming the equality of variance, we can have the estimations and test the hypotheses for each element of the model. Fig. 2 demonstrates the structural equation modeling and the relationship between variables.

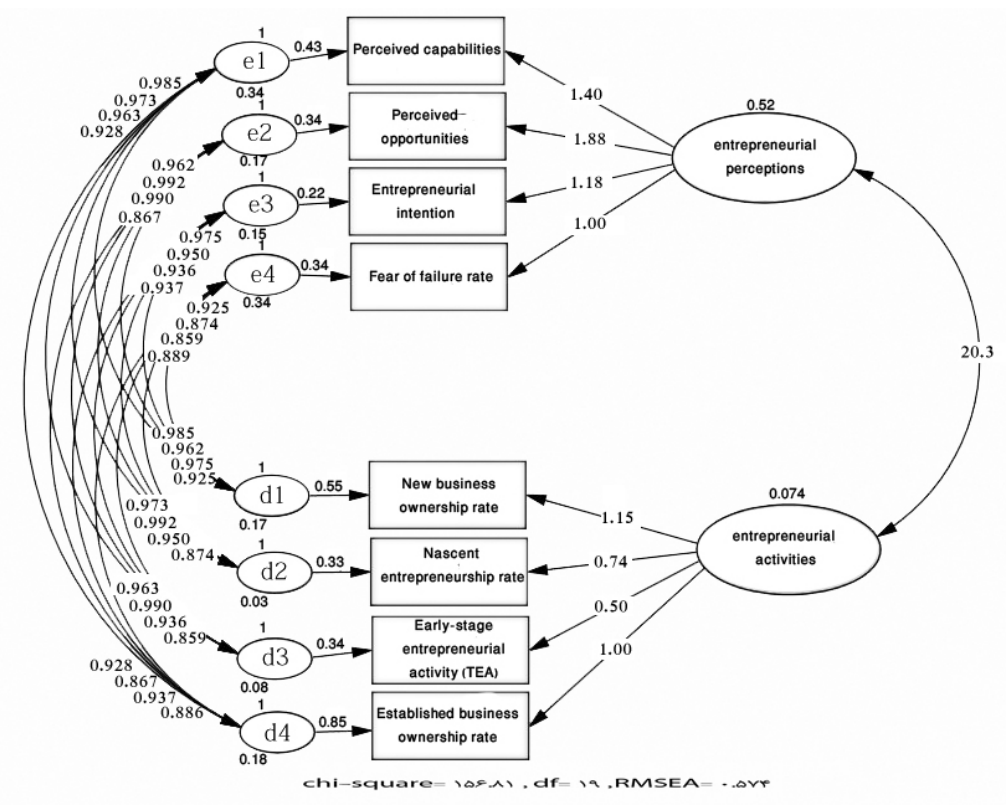

Fig. 2. Structural equation modeling for the main variables

For evaluating the fitness of the model variables and the final model, we can use many indices like the ones shown in Table 1.

Table 3

Fitness indices of the model

\begin{tabular}{llllll}
\hline & $A G F I^{4}$ & $G F I$ & $C F I^{3}$ & $N F I^{2}$ & $R M S E A^{1}$ \\
\hline Acceptance criteria & closeness to & $\begin{array}{l}\text { closeness } \\
\text { to 1 }\end{array}$ & $\begin{array}{l}\text { closeness } \\
\text { to 1 }\end{array}$ & $\begin{array}{l}\text { closeness } \\
\text { to 1 }\end{array}$ & $\begin{array}{l}\text { closeness } \\
\text { to zero }\end{array}$ \\
\hline $\begin{array}{l}\text { statistical indices of the model for } \\
\text { entrepreneurial activities and } \\
\text { perceptions }\end{array}$ & -0.136 & 0.40 & 0.76 & 0.73 & 0.57 \\
\hline Results & & & & & \\
\hline
\end{tabular}

According to the obtained results from the above Table 3, two variables are not acceptable; however, this does not imply that we can reject the model. Comparing the presented indices and the acceptable value for model fitness shows that there is a suitable fitness for the research model. Moreover, since in many cases the correlations are close to 1 , we can claim that the correlations are significant even at the $\mathrm{P}$ value of 0.01 . Based on the research hypotheses and the structural equation modeling, the effect 
of entrepreneurial activities on entrepreneurial perceptions equals to 20.3. Therefore, in the studied countries, there is a strong effect of entrepreneurial activities on entrepreneurial perceptions. We can claim that with the enhancement of entrepreneurial perceptions through education, entrepreneurial activities will have a considerable improvement. Fig. 2 shows the results of our study and the following is the summary of our results,

Nascent entrepreneurship rate $=0.74$ Entrepreneurial perceptions +0.33 e1

New business ownership rate $=1.15$ Entrepreneurial perceptions $+0.55 \mathrm{e}_{2}$

Established business ownership rate $=1$ Entrepreneurial perceptions $+0.85 \mathrm{e}_{3}$

Early-stage entrepreneurial activity $=0.50$ Entrepreneurial perceptions $+0.34 \mathrm{e}_{4}$

Perceived opportunities $=1.40$ entrepreneurial activities $+0.43 \mathrm{~d}_{1}$

Perceived capabilities $=1.88$ entrepreneurial activities $+0.34 \mathrm{~d}_{2}$

Entrepreneurial intention $=1.18$ entrepreneurial activities $+0.22 \mathrm{~d}_{3}$

Fear of failure rate $=1$ entrepreneurial activities $+0.34 \mathrm{~d}_{4}$

\section{Table 4}

The Results of Research hypotheses

\begin{tabular}{llc}
\hline Hypotheses & Description of the hypotheses & Results \\
\hline 1 & $\begin{array}{l}\text { There is a relationship between the observed variables of and those of } \\
\text { entrepreneurial activities }\end{array}$ & $\checkmark$ \\
2 & $\begin{array}{l}\text { There is a relationship between the latent variable of entrepreneurial } \\
\text { perceptions and observed variables of entrepreneurial activities }\end{array}$ & $\checkmark$ \\
3 & $\begin{array}{l}\text { There is a relationship between the latent variable of entrepreneurial } \\
\text { activities and its observed variables }\end{array}$ & $\checkmark$ \\
4 & Entrepreneurial perceptions have an effect on entrepreneurial activities & $\checkmark$ \\
\hline
\end{tabular}

As we can observe, the research hypotheses are confirmed.

\section{Conclusion}

Generally, there is a little evidence about the importance of entrepreneurial perceptions for entrepreneurial activities throughout the world. Researchers such as Bosma have indicated that earlystage entrepreneurial activities in each region contain less amount of changes compared with entrepreneurial activities in general (Bosma \& Schutjens, 2007). In addition, there are some evidences on the importance of fear of failure rate in starting a business in a region. The improvement of entrepreneurship has a substantial impact on the development of societies. In this regard, one of the basic aims of GEM is to study the relationship between entrepreneurial activities and perceptions among the member countries of this consortium. However, the development of entrepreneurship needs continuous investigation of entrepreneurial activities and perceptions in the country. The results of the structural equation modeling for testing the research hypotheses showed that for the relationship between the variables of entrepreneurial activities and perceptions, the standardized coefficient was 1.01 and the significance coefficient was 20.3, which is well above the minimum desired level, 1.96. As a result, one can infer that, among the studied countries, entrepreneurial perceptions have a substantial influence on entrepreneurial activities. Based on the findings of the study, which indicate the significant influence of perceptions on activities and Pearson correlation coefficient which shows the significant relationship between these two variables, one can suggest that, with respect to entrepreneurial perceptions, the behavior and features of nascent entrepreneurs, new business owners, and established business owners necessarily leads to a significant effect on entrepreneurial activities in these countries. It is also recommended that entrepreneurial opportunities are detected and prioritized in each of the provinces of the country. Furthermore, it is suggested that the impact of entrepreneurial perceptions on activities is studied in each region of the country. 
Finally, we can help the improvement of entrepreneurship level by designing the strategic development of entrepreneurship document in Iran.

\section{Reference}

Bosma, N. \& Schutjens, V. (2007). Outlook on Europe: Patterns of Promising Entrepreneurial Activity in European Regions. Tijdschrift voor economische en sociale geografie 98(5), 675-686.

Bosma, N.S., Van Stel, A. \& Suddle, K. (2008). The geography of new firm formation: Evidence from independent start-ups and new subsidiaries in the Netherlands. International Entrepreneurship and Management Journal, 4 (2), 129-146.

Casson, M. \& Wadeson, N. (2007). The Discovery of Opportunities: Extending the Economic Theory of the entrepreneurship. Small Business Economics, 28, 285-300.

Casson, M. (1982). The Entrepreneur: An Economic Theory. Martin Robertson, Oxford.

De Clercq, D., \& Bosma, N.S. (2008). An exploratory study of international commitment by nascent and existing firms. Journal of Small Business and Entrepreneurship, 21(3), 223-237.

Bosma, N.S. \& De Clercq, D. (2008). An Exploratory Study of International Commitment by Nascent and Existing Firms. Journal of Small Business and Entrepreneurship, 21(3), 223-237.

Global entrepreneurship Monitor (2008). Available at http://wwww.entreprenorskapsforum.se

Global entrepreneurship Monitor (2009). Available at http://wwww.entreprenorskapsforum.se

Global entrepreneurship Monitor (2010). Available at http://wwww.entreprenorskapsforum.se

Kruger, J., Schneider, J., \& Westermann, R. (2006). Clearview: An interactive context preserving hotspot visualization technique. Visualization and Computer graphics, IEEE Transactions on 12(5), 941-948.

Nawaser, K., Sadeq Khaksar, S. M., Shakhsian, F., \& Afshar Jahanshahi, A. (2011). Motivational and legal barriers of entrepreneurship development. International Journal of Business and Management, 6(11), 112-118.

Schumacher, R. A., \& Lvmks, R.G. (2010). Structural Equation Modeling. $3^{\text {rd }}$ ed. Routledge.

Shane, S. (2000). Prior knowledge and the discovery of entrepreneurial opportunities. Organization Science 11, 448-469.

Timmons, J.A., \& Spinelli, S. (2004). New Venture Creation Entrepreneurship for the 21st Century, $6^{\text {th }}$ ed. McGraw-Hill.

Venkataraman, S. (2002). The distinctive domain of entrepreneurship research: An editor's perspective. Advances in entrepreneurship, 3, 119-38.

Wennekers, S., van Stel, A., Thurik, R., \& Reynolds, P. (2005). Nascent entrepreneurship and the level of economic development. Small Business Economics, 24(3), 293-309.

Zali, M. (2007). Global Entrepreneurship Monitor (Introduction). Tehran Entrepreneurship University (In Farsi).

Zali. M., \& Razavi, M. (2008). Barriers to Entrepreneurship Development in Iran. Tehran Entrepreneurship University, (In Farsi).

Zali, M., R, M., Yadolahi, J., \& Kordnaich, A. (2010). Global entrepreneurship Monitor in Iran. Institute of Labor and Social Affairs, (In Farsi). 